\title{
THE UTILITY OF INTERNATIONAL INVESTMENT ARBITRATION IN SOVEREIGN DEBT RESTRUCTURING
}

\begin{abstract}
Abubakar Isa Umar ${ }^{*} \&$ Muhammad Bello**
Adjudicating claims arising from sovereign debt default in the absence of an acceptable international legal framework on the subject has raised fundamental questions regarding the appropriateness of employing investor-state dispute settlement mechanism under international investment law to address such claims. Tribunals have been polarized and scholars have expressed divergent views. Debtors and creditors are in a dilemma. Using some ICSID awards, this article examines the contending perspectives on the use of investment arbitration in sovereign debt restructuring claims. The article argues that investment arbitration and sovereign debt restructuring ought not to be in a collision course if we reflect on the significance of parties' consent in general international law. It argues that accepting international investment arbitration as a method of sovereign debt crises resolution will create the needed balance, certainty and ultimately enhance creditor confidence and debt sustainability for debtor countries. However, for this to succeed the observed lapses in the current ISDS mechanism must be addressed.
\end{abstract}

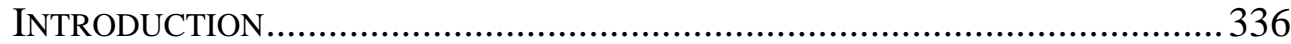

I. INVESTMENT ARBITRATION AND ISSUES IN SOVEREIGN DEBT CRISIS .......339

A. International Investment Arbitration \& the ICSID.....................339

B. $\quad$ Sovereign Debts and Default in International Finance............. 342

II. THE PROBLEMS OF SDR: INTERNATIONAL ARBITRATION TO THE RESCUE?

III. The CONTENDING PERSPECTIVES AND THE Position OF ARBITRAL

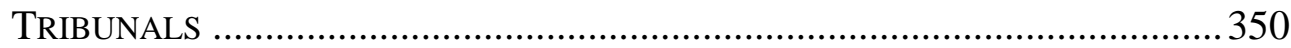

A. Arguments against International Arbitration ........................... 350

B. $\quad$ Arguments in Favor of International Investment Arbitration... 352

C. The Perspective of ICSID Tribunals........................................ 355

IV. INVESTMENT ARBITRATION AND THE GAP IN THE LEGAL FRAMEWORK ON

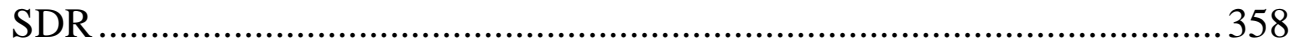

A. $\quad$ The Future of Investment Arbitration in SDR......................... 360

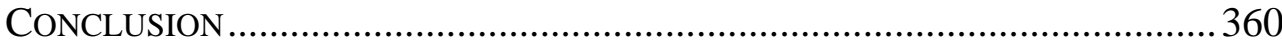

\footnotetext{
${ }^{*}$ MCIArb (London), Ph.D. Fellow, School of Law, University of Portsmouth, UK. Research fields: International Economic Law, International Arbitration.

${ }^{* *}$ LLM (BUK) and Lecturer at Faculty of Law, Bayero University, Kano. Research fields: Sovereign

Debt Adjudication and Cross-Border Insolvency.
} 


\section{INTRODUCTION}

The central question on the use of investment treaty arbitration in adjudicating claims arising from sovereign debt default was lucidly raised by Prof. George Abi Saab in his dissenting opinion in the famous Abaclat's case in the following words: "Do ICSID tribunals have jurisdiction over sovereigndebt instruments issued internationally, expressed in foreign currency and payable abroad, governed by various external laws and subject to the jurisdiction of various external courts, and traded as dematerialised security entitlements in global capital markets?" ${ }^{1}$ This question adds precision to an increasingly unsettled area of international adjudication. The question also reflects the growing controversies in this area. Indeed, over the years the utility of international investment arbitration in Sovereign Debt Restructuring (SDR) has generated a lot of scholarly discourse and sharply polarized academic opinions on the subject. ${ }^{2}$ But despite initial skepticism, international arbitration is gradually becoming an option for addressing claims arising from sovereign debt defaults. ${ }^{3}$ This is understandable because of the absence of a legal framework for SDR at the international level ${ }^{4}$ and

\footnotetext{
${ }^{1}$ Abaclat and Others $v$. The Argentine Republic, Decision on Jurisdiction and Admissibility, Dissenting Opinion of Professor Georges Abi-Saab, at para 269,

https://icsid.worldbank.org/ICSID/FrontServlet?requestType=CasesRH\&actionVal=showDoc\&docId =DC5313_En\&caseId=C95 (last visited November 12, 2016) (hereafter "Abaclat Dissenting Opinion").

${ }^{2}$ See for instance Michael Waibel, Opening Pandora's Box: Sovereign Bonds in International Arbitration, 101 AJIL 711-759 (2007) (hereafter Waibel, Opening Pandora's Box); O. Sandrock,

The Case for More Arbitration when Sovereign Debt is to be Restructured: Greece as an Example, 23 AMERICAN REVIEW OF InTL ARBitRation 507 (2012) (hereafter Sandrock, More Arbitration); E. Norton, International Investment Arbitration and the European Debt Crisis, 13 CHICAGO JouRnAL OF INTERNATIONAL LAW 291 (2012), http://chicagounbound.uchicago.edu/cjil/vol13/iss1/11 (accessed 13 August 2016) (hereafter "Norton, Intl Arbitration and the European Debt Crisis"); K. P. Gallagher, Financial Crises and International Investment Agreements: The Case of Sovereign Debt Restructuring, 3(3) Global Policy 362 (2012) (hereafter Gallagher, Case of Sovereign Debt Restructuring); R. D. Thrasher \& K. P. Gallagher, Mission Creep: The Emerging Role of International Investment Agreements in Sovereign Debt Restructuring, BOSTON UNIVERSITY CENTER FOR FINANCE, LAW \& POLICY WORKING PAPER 003 2/2016 (2016), http//www.bu.edu/bucflp (last visited accessed October 20, 2016) (hereafter Thrasher \& Gallagher, Mission Creep); J. Ostřanský, Sovereign Default Disputes in Investment Treaty Arbitration: Jurisdictional Considerations and Policy Implications, 3(1) GROJIL 27-58 (2015),

https://groningenjil.files.wordpress.com/2015/05/grojil_vol3-issue1_ostransky_.pdf_(last visited accessed October 12, 2016) (hereafter Ostřanský, Sovereign Default Disputes in Arbitration); M. D. Nolan, et al. Leviathan on Life Support: Restructuring Sovereign Debt and International Investment Protection after Abaclat 485, http://ssrn.com/abstract=2248096 (accessed October 12, 2016) (hereafter M. D. Nolan, et al. Leviathan on Life Support).

${ }^{3}$ M. Waibel, Opening Pandora's Box (n 2) 711.

${ }^{4}$ UNCTAD, Sovereign Debt Workout: Going Forward, Roadmap and Guide, UNCTAD2015 12-15 (hereafter UNCTAD, Sovereign Debt Workout Guide).
} 
the fact that international investment agreements (IIAs) typically make provisions for investment treaty arbitration and other substantive investment protections. ${ }^{5}$ Investors have been availing themselves of these investment protections. ${ }^{6}$ However, extending these guarantees to the realm of sovereign debt default is not without challenges partly because of the novelty of the claims as well as the uncertainty, disparity and lack of uniformity characterizing the current legal regime on SDR. ${ }^{7}$ Thus, while some scholars consider investor-state dispute settlement (ISDS) through arbitration in disputes arising from sovereign debt default and restructuring as an obstacle to effective SDR by debtor countries, ${ }^{8}$ others maintain that investment treaty arbitration offers a viable and fairly balanced option for both sovereign debtors and creditors. ${ }^{9}$ Recent incidents of sovereign default have shown that an ISDS mechanism can offer thousands of creditors the rare opportunity of dragging sovereign debtors before arbitral tribunals in order to ensure the enforcement of their claims using the substantive guarantees provided under Bilateral Investment Treaties (BITs) between their home state and the sovereign debtors. Before the advent of investment treaty arbitration, enforcement of sovereign debt took a variety of forms including intervention by creditors' States often through the use of force. ${ }^{10}$ BITs seem to have changed the dynamics by providing an alternative route through investment treaty arbitration. ${ }^{11}$ In addition, countries are cautiously

\footnotetext{
${ }^{5}$ M. SORnARAJah, The InTERnAtional LAW On Foreign InVESTMEnT 276-362 (3rd ed., Cambridge University Press 2010).

${ }^{6}$ Gus Van Harten, Private Authority and Transnational Governance: The Contours of the International System of Investor Protection, 12(4) REVIEW OF INTERNATIONAL POLITICAL ECONOMY 600, 602 (2005).

${ }^{7}$ UNCTAD, Sovereign Debt Workout Guide, (n 4) 12-15. See also L. Brahm, Legitimacy in Global Governance of Sovereign Default: The Role of International Investment Agreements, PIPE Working Paper No. 16 Centre for International Political Economy, Berlin (2013) (hereafter "Brahm, Legitimacy in Global Governance of Sovereign Default").

${ }^{8}$ Waibel, Opening Pandora's Box (n 2); K. P. Gallagher, The New Vulture Culture: Sovereign Debt Restructuring and Trade and Investment Treaties, IDEAs Working Paper No 02/2011, IDEAs New Delhi (2011), http://unctad.org/en/Docs/webdiaepcb2011d3_en.pdf; Gallagher, Case of Sovereign Debt Restructuring (n 2); Thrasher \& Gallagher, Mission Creep (n 2); Ostřanský, Sovereign Default Disputes in Arbitration (n 2)

${ }^{9}$ Norton, Intl Arbitration and the European Debt Crisis (n 2); MD Nolan and others, Leviathan on Life Support (n 2).

${ }^{10}$ WMC Weidemaier, Contracting for State Intervention: the Origins of Sovereign Debt Arbitration, 73 LAW AND CONTEMPORARY PROBLEMS 335 (2010).

${ }^{11}$ UNCTAD, Recent Developments in Investor-State Dispute Settlement IIA Issues Note (2013), http://unctad.org/en/PublicationsLibrary/webdiaepcb2013d3_en.pdf (last visited Dec. 21, 2016) (hereafter UNCTAD, ISDS 2013); UNCTAD, Recent Trends in IIAs and ISDS, IIA Issue Note, UN, New York and Geneva, 2 (2015), available at http://unctad.org/en/PublicationsLibrary/webdiaepcb2015d1_en.pdf (last visited Dec. 21, 2016) (hereafter UNCTAD, ISDS 2015).
} 
remodeling their BITs with some ousting sovereign debt instruments from arbitral jurisdiction ${ }^{12}$ while others are removing or downplaying the ISDS provisions in their BITs. ${ }^{13}$ Other countries simply denounced their ICSID membership on ideological or other grounds. ${ }^{14}$

This article examines the contending perspectives on the use of investment arbitration in sovereign debt crises through the juris prudence of International Center for the Settlement of Investment Disputes (ICSID). Over the past decade, ICSID tribunals have become the locus of this debate with holdout bondholders increasingly using them to seek enforcement of their claims. ${ }^{15}$ The ICSID awards also re-echoed the dilemma of creditors in the current regime of SDR. They equally raised fundamental questions regarding the capacity of the international financial system to deal with issues related to sovereign debt default. In other words, they re-ignited the debate and the calls for a global legal framework on SDR. ${ }^{16}$

Against the backdrop of the perspectives of both ICSID tribunals and scholars as well as the recurring sovereign debt crises around the world, this article argues that minimizing sovereign debt crises requires some form of flexibility with a sound theoretical basis and a careful reconnection to the root of general international law. The article argues that investment arbitrations and SDR ought not to be in a collision course if we reflect on

\footnotetext{
${ }^{12}$ Thrasher \& Gallagher (n 2) 17-19. By February 2015, at least 45 countries were revising their model BITs. See UNCTAD, ISDS 2015 (n 11) 1.

${ }^{13}$ See for instance, the Australia-US Free Trade Agreement (2004). See also J. Pohl, K. Mashigo and A. Nohen, Dispute Settlement Provisions in International Investment Agreements: A Large Sample Survey, OECD Working Papers on International Investment 2012/02 OECD 11 (2012) (hereafter "Pohl and others ISDS Sample Survey").

${ }^{14}$ For example, Ecuador, Venezuela and Bolivia. See IA Vincentelli, The Uncertain Future of ICSID in Latin America, 16 LAw \& Bus Rev Am 409, 410 (2010). There are over 150 signatories to the Convention. For the contracting parties see List of Contracting States and Other Signatories of the Convention, ICSID,

https://icsid.worldbank.org/ICSID/FrontServlet?requestType=CasesRH\&actionVal=ShowHome\&pag eName=MemberStates_Home (last visited May 11, 2015).

${ }^{15}$ Prominent among them are: Abaclat \& Others v. The Argentine Republic, Decision on Jurisdiction and Admissibility (ICSID) ICSID Case NO. ARB/07/5 [4 $4^{\text {th }}$ August, 2011] also reported in 52 ILM 667 (2013),

https://icsid.worldbank.org/ICSID/FrontServlet?requestType=CasesRH\&actionVal=showDoc\&docId =DC5313_En\&caseId=C95 (hereafter Abaclat); Geovanni Alemanni v. Republic of Argentina, ICSID Case No ARB/07/8 (17 ${ }^{\text {th }}$ November, 2014),

https://icsid.worldbank.org/ICSID/FrontServlet?requestType=CasesRH\&actionVal=showDoc\&docId =DC5132_En\&caseId=C100 (last visited December 12, 2016) (hereafter "Alemanni $v$. Argentina"); Poštová Banka, A. S. and Istrokapital S. E. v The Hellenic Republic, ICSID Case No. ARB/13/8, https://icsid.worldbank.org/ICSID/FrontServlet?requestType=CasesRH\&actionVal=showDoc\&docId =DC5752_En\&caseId=C2823 (last visited December 23, 2016) (hereafter "Postova Banka").

${ }^{16}$ In Abaclat, Argentina argued that "opening of ICSID arbitration with regard to sovereign debt restructuring would ... go against current efforts to modernize foreign debt restructuring process". See Abaclat ILM (2013) 755.
} 
the significance of parties' consent in general international law. A fundamental element missing in this discourse has been the failure to recognize the fact that today, both international investment law and modern sovereign debt scheme largely involve consensual "investor-state" relationships and that the increasing rejection of this reality by some arbitrators and scholars is unhelpful to the overall goal of developing an effective legal framework for SDR. Thus, accepting international investment arbitration as a method of sovereign debt crises resolution will create the needed balance, certainty and ultimately enhance creditor confidence and debt sustainability for debtor countries. However, for this to succeed the observed lapses in the current ISDS mechanism must be addressed.

To articulate the above arguments, the rest of the article is structured as follows: Section I examines the nature of international investment arbitration as well as the nature of sovereign debt, sovereign default and sovereign debt restructuring. Section II shows how international arbitration is gradually being employed to adjudicate over disputes arising from sovereign debt default. Section III reviews the contending positions to see their respective arguments on the issue and to support the need for ISDS in SDR. Section IV advances the argument that with the blessing of parties' consent investment arbitration is suitable for adjudicating disputes arising from SDR. Section V concludes with some suggestions.

\section{INVESTMENT ARBITRATION AND ISSUES IN SOVEREIGN DEBT CRISIS}

To appreciate the contending views on the use of investment arbitration in disputes arising from SDR, a conceptual foundation is important here.

\section{A. International Investment Arbitration \& the ICSID}

Since the second half of the 20th century, investor-state dispute settlement has become a central feature of international investment law. ${ }^{17}$ ISDS is a mechanism for ordered resolution of investment disputes mostly through invocation of arbitration provisions of bilateral and other investment agreements. ${ }^{18}$ In the words of Abbott and others, ISDS "grants investors the right to call for arbitration in the event that they believe that

\footnotetext{
${ }^{17}$ Advisory Council on Intl Affairs, International Investment Dispute Settlement: From Ad hoc Arbitration to a Permanent Court 7 (The Hague, 2015).

${ }^{18} \mathrm{R}$. Abbott and others, Demystifying Investor-State Dispute Settlement, ECIPE Occasional Paper No 52 (2014), http://www.ecipe.org/app/uploads/2014/12/OCC52014_1.pdf (last visited November 20, 2016) (hereafter Abbot and others, Demystifying ISDS).
} 
the government has violated such an agreement." ${ }^{19}$ It may also include recourse to local courts and alternative disputes resolution (ADR) mechanisms such as mediation and conciliation. ${ }^{20}$ Arbitration as a concept involves a determination of disputes by an independent third party other than the court pursuant to the agreement of parties. ${ }^{21}$ It is an adversarial process leading to a binding, enforceable award. ${ }^{22}$ Parties have crucial role in constituting the tribunal. Therefore, international investment arbitration allows investors' access to a neutral, depoliticized and relatively independent and flexible adjudication forum in the event of a host government's untoward conducts amounting to either an expropriation or anyviolation of a treaty obligation or actionable guarantee under the treaty. ${ }^{23}$ Indeed, ISDS is the cornerstone of investment protection as it "serves as a procedural enforcement mechanism for the core substantive provisions" of BITs. ${ }^{24}$ The substantive investment guarantees normally come in the form of common investment standards such as the fair and equitable treatment (FET) standard, most favored nation (MFN) and national treatment (NT) standards. $^{25}$

As noted above, prior to the institutionalization of ISDS, foreign investors were at the mercy of their home states. ${ }^{26}$ Today however, thousands of BITs enable investors to directly drag their host governments to arbitral tribunals for adjudication thereby eliminating the circuitous diplomatic route with its attendant negatives. ${ }^{27}$ Although there are notable variations in the language of the ISDS and the expropriation provisions of these BITs, there seems to be a general consensus about their ultimate objective of creating a level-playing ground for investors vis-à-vis their host governments when a dispute arises. ${ }^{28}$ These are perhaps the most important

\footnotetext{
${ }^{19} \mathrm{Ibid}$, at 3.

${ }^{20}$ UNCTAD, Course on Dispute Settlement in International Trade, Investment and Intellectual Property: ICSID (UNCTAD 2003) 7-19.

${ }^{21}$ E. A. Martin, (ed.) OXFord Dictionary of LAw $5^{\text {th }}$ ed. 31 (OUP, 2003).

${ }^{22}$ C. Schreuer, International Center for the Settlement of Investment Disputes (ICSID) para 23, http://www.univie.ac.at/intlaw/wordpress/pdf/100_icsid_epil.pdf (last visited December 21, 2016).

${ }^{23}$ UNCTAD ISDS 2014 (n 11) 25-29. See also UNCTAD, Investment Law, Investment Policy Monitor, (UNCTAD 2016) http://unctad.org/en/PublicationsLibrary/webdiaepcb2016d5_en.pdf (last visited Dec. 21, 2016).

${ }^{24}$ UNCTAD, Investor-State Disputes: Prevention and Alternatives to Arbitration UNCTAD Series on International Investment Policies for Development, (UNCTAD 2010) at p. xxii.

${ }^{25}$ M. Sornarajah, (n 5) 233-255.

${ }^{26}$ WMC Weidemaier, (n 10) 337-340.

${ }^{27}$ The number of IIAs is growing. As at 2014 for example, there were over 3268 BITs in force. See UNCTAD, Recent Trends in IIAs and ISDS, IIA Issue Note, 2 (UNCTAD 2015), http://unctad.org/en/PublicationsLibrary/webdiaepcb2015d1_en.pdf (last visited December 22, 2016).

${ }^{28}$ M. Jean-Frédéric \& J. Gagné, What Can Best Explain the Prevalence of Bilateralism in the Investment Regime?, 36 INTERNATIONAL JOURNAL OF POLITICAL ECONOMY 53-74 (2007).
} 
provisions in modern BITs. ${ }^{29}$

Most BITs specify the conditions for recourse to arbitration as well as the forum for the resolution of the disputes. ${ }^{30}$ Although ICSID is one of many arbitral institutions, it is however, at the center of the sovereign debt restructuring debate as revealed by the increasing number of cases being handled by ICSID tribunals. ICSID, as an institution of the World Bank Group (WB), was established under the Washington Convention to primarily provide the institutional framework that will effectively facilitate the settlement of investment disputes between foreign investors and their host governments. ${ }^{31}$ Apart from providing an arbitration forum for investors, it enables States to improve their investment climate, attract foreign capital by allaying the fears of investors and avoiding diplomatic tensions or unnecessary international litigations. ${ }^{32}$ Not surprisingly, today ICSID is the preferred arbitral institution for aggrieved investors. ${ }^{3.3}$

The jurisdiction of ICSID tribunals is determined by an "intersection" between the Washington Convention and the investment treaty upon which a complaint is founded. ${ }^{34}$ But, as noted above, the jurisdiction of ICSID tribunals over creditors' claims arising from sovereign debt default has remained deeply controversial. ${ }^{35}$ As will be discussed in Section III infra, one of the key objectives of the WB in establishing the ICSID was to provide foreign investors a direct access to "an international tribunal in the field of financial and economic disputes with Governments". ${ }^{36}$ Disputes arising from sovereign debt defaults should ordinarily be part of "financial and economic disputes with governments". But until the Argentine debt

\footnotetext{
${ }^{29}$ An OECD study found that $93 \%$ of 1660 BITs studied had ISDS provisions. See Pohl and others, ISDS Sample Survey (n 13) 7.

${ }^{30}$ UNCTAD, Course on Dispute Settlement in International Trade, Investment and Intellectual Property: Dispute Settlement ICSID 5-6 (UNCTAD 2003); M. Sornarajah, (n 5) 249-250.

${ }^{31}$ Convention on the Settlement of Investment Disputes Between States and Nationals of Other States, 18 March 196517 UST 1270, 575 UNTS 159 (the Washington Convention).

${ }^{32}$ D. Gaukrodger \& K. Gordon, Investor-State Dispute Settlement: A Scoping Paper for the Investment Policy Community, 2012/03 OECD WorkING PAPERS ON INTERNATIONAL INVESTMENT 10 (2012).

${ }^{33}$ C. Schreuer, ICSID at para 7, http://www.univie.ac.at/intlaw/wordpress/pdf/100_icsid_epil.pdf (last visited November 10, 2016).

${ }^{34}$ Washington Convention (1965) Article 25.

${ }^{35}$ Waibel, (n 2); Norton, Intl Arbitration and the European Debt Crisis (n 2); Thrasher \& Gallagher (n 2) 20 .

${ }^{36}$ Note by A. Broches Settlement of Disputes between Governments and Private Parties in History of the ICSID Convention Vol II-1, (ICSID 2009) 1-2,

https://icsid.worldbank.org/en/Documents/resources/History\%20of\%20ICSID\%20Convention\%20\%20VOLUME\%20II-1.pdf; Y. Krayvoi, International Centre for Settlement of Investment Disputes (ICSID) (January 2010) Intergovernmental Organizations-Suppl 37, para27, http://ssrn.com/abstract=1449363 (last visited November 9, 2016).
} 
crisis of 2001, sovereign debtors were rarely brought to ICSID-based arbitration for debt default perhaps because of the uncertainty regarding the nature of investments capable of conferring jurisdiction on ICSID tribunals. ${ }^{37}$ Though it did not directly define what is an investment, Article 25 of the Washington Convention provides the jurisdictional base for ICSID arbitration, which is the consent of the parties plus "a legal dispute arising directly out of an investment" between a national of a State party and a State party to the Washington Convention. Whether sovereign debts qualify as "investment" under the Washington Convention for the purpose of conferring jurisdiction on ICSID Tribunals is still debatable point.

\section{B. Sovereign Debts and Default in International Finance}

Modern international finance involves the "provision of finance at a financial center by foreign lenders to foreign borrowers largely in a currency which is not the currency of the financial center" ${ }^{38}$ Therefore, the problems associated with sovereign debt largely reflect the contextual and multijurisdictional complexities that characterize international finance itself. It is important to examine the nature of sovereign debt and default here.

\section{Nature and Forms of Sovereign Debts}

\section{(1) Sovereign Debt as Contract}

It is debatable whether sovereign debt is a form of loan contract. ${ }^{39}$ But in so far as there is a lender providing funds to a borrower in need, then sovereign debt may qualify as a form of "loan" contract. ${ }^{40}$ The concept of "loan" presupposes the mutuality of minds that characterizes general contracts. ${ }^{41}$ Parties freely assume obligations to realize commercial objectives. Loan is however, a unique form of contract because of its inherent character of asymmetrical performance: One party lends and the

\footnotetext{
${ }^{37}$ OECD, International Investment Law: Understanding Concepts and Tracking Innovations (OECD 2008) 46-75.

${ }^{38}$ R. V. Tennekoon, The Law and Regulation of International Finance 2 (Butterworth 1991).

${ }^{39}$ See for instance Fedax N.V. v. Republic of Venezuela ICSID Case No ARB/96/3 Decision on Objection to Jurisdiction (11 June 1997)(1998) 37 ILM 1378; Ceskoslovenska Obchodni Banka AS (CSOB) v. The Slovak Republic ICSID Case No ARB/97/4 Decision on Jurisdiction (24 May 1999); Cf Postova Banka Decision (n 15).

${ }^{40}$ Alpha Projektholding GMBH v. Ukraine ICSID Case No ARB/07/16 Award (20 October 2010) 273, where the Tribunal observed that it is unaware of any ICSID decision that has held that a loan cannot be an "investment". Cf Postova Banka Decision (n 15), paras 335-338.

${ }^{41}$ M Bello, Globalization, Sovereign Debt Crises and the Demise of Sovereignty: Towards a Legal Framework for Sovereign Debt Restructuring (2016) 2 Bayero Journal of Private \& Commercial Law 42,43 .
} 
other subsequently repays over a period of time. ${ }^{42}$ In the words of Aguir "payments are typically contingent only on time". ${ }^{43}$ This asymmetrical performance is equally an inherent feature of sovereign debt. But like other forms of contract, effective and efficient legal system, certainty and predictability in terms of enforcement are of fundamental importance in assuring the parties to loan contracts of the desired legal protection. ${ }^{44}$ For the creditors, this assurance is critical to the integrity of the agreement itself as it provides them the needed protection against possible default.

Borrowing is a viable financing option for entrepreneurs, corporations, public entities and national and sub-national governments. Indeed, for countries borrowing is generally considered to be good for development purposes. ${ }^{45}$

Therefore, sovereign debt is a product of loan contract and consists of the accumulated financial undertakings or the aggregate of all claims against a country as monitored and recognized by countries, international financial institutions and the international financial system in general. ${ }^{46}$ It is a "debt issued or guaranteed by the government of a sovereign state". ${ }^{47}$ It has certain peculiar features that distinguish it from other forms of borrowing: It is an instrument of monetary policy; it is susceptible to market volatility, internal and external forces and general political risks; and "creditors have much more limited legal resources if a sovereign debtor fails to make a contracted payment". ${ }^{48}$ It may not fit the character of a loan under a municipal system but it is submitted that it is a loan nonetheless. The sovereign status of the borrower does not change the character of the transaction although it makes this loan unique and less attractive to lenders. ${ }^{49}$

(2) Forms of Sovereign Debt

Borrowing by governments takes a variety of forms: It could be either domestic or external depending on the governing laws and sources of such funds. While domestic borrowing by governments is normally regulated through specific legislative instruments without much difficulty, external borrowing presents particularly complex enforcement and multi-jurisdictional

\footnotetext{
${ }^{42}$ Lee C. Buchheit, Law, Ethics, and International Finance, 70(3) LAW AND CONTEMPORARY PROBLEMS $1-6$ (2007).

${ }^{43}$ M. Aguir, Sovereign Debt: Empirical Facts 2-3 (2015).

${ }^{44}$ Lee C. Buchheit (n 42) 2.

${ }^{45}$ R. M. Nelson, Sovereign Debt in Advanced Economies: Overview and Issues for US Congress, Congressional Research SERvice 2 -3 (Washington DC, 2013) (hereafter Nelson, Sovereign Debt in Advanced Economies).

${ }^{46}$ J. BLACK, (ED.) OXFORD Dictionary OF ECONOMICS 238 ( $2^{\text {nd }}$ edn, OUP 2004).

${ }^{47}$ US Das and others, Restructuring Sovereign Debt: Lessons from Recent History 4 (2012).

${ }^{48}$ Postova Banka (n 15), paras 318-324.

${ }^{49}$ G. R. Delaume, Sovereign Immunity and Public Debt, 23(4) THE INTERNATIONAL LAWYER 811825 (1989)
} 
issues. Domestic debt is denominated in local currency and exclusively controlled by the domestic legal system and therefore is not normally subject to international investment arbitrational though it may be susceptible to adverselegislative measures or other actions of government. ${ }^{50}$ On the other hand, "external debt is expressed in some foreign currency, typically payable abroad, governed by some external law and subject to the jurisdiction of externalcourts". ${ }^{51}$ Thus, different systems of law are potentially applicable. ${ }^{52}$ Conflicts of law and jurisdiction clauses are invariably inserted by the parties to determine the forum and the "proper" (or governing) law. ${ }^{53}$

Furthermore, external debt may come in the form of bilateral official loan between governments or their authorized agencies. ${ }^{54}$ Secondly, it could be a debt owed to international financial institutions (IFIs). These two forms of loan are often described as official loans. ${ }^{55}$ Private investors are not involved. But these forms of borrowing are gradually being de-emphasized due to some concerns of moral hazards and the flexibility of bonds. ${ }^{56}$ External debt can also be in the form of a "syndicated bank loan" otherwise called "multi-currency loans" consisting of separate loans made by different banks to the same borrower. ${ }^{57}$ In both official and syndicated bank loans there is a sort of direct relationship between the borrower and the lender. This is unlike sovereign bonds as we now examine.

(3) Sovereign Bonds

The commonest but complex form of sovereign financing today is by issuing of sovereign bonds. It enables sovereign borrowers to obtain longterm financing by way of issuing bonds in international capital markets. Bonds are fixed-income securities by which a bondholder extends money to an entity for a defined period of time and at certain interest rates. ${ }^{58}$ They are different from domestic bonds. ${ }^{59}$ Unlike sovereign bonds, domestic bonds raise little or no conflict of law, enforcement and related jurisdictional problems. Sovereign bonds are issued in a currency different from the

\footnotetext{
${ }^{50}$ International Law Association, State Insolvency: Options for the way Forward a Revised Report of the Sovereign Insolvency Study Group, presented at the Hague Conference, August, 2010 (hereafter ILA, State Insolvency) 9.

${ }^{51}$ Ibid.

${ }^{52}$ RV Tennekon (n 38) 15.

${ }^{53}$ Ibid.

${ }_{55}^{54}$ ILA, State Insolvency (n 50) 9.

${ }^{55}$ Ibid.

${ }^{56}$ S. Ghosal \& M. Miller, Co-Ordination Failure, Moral Hazard and Sovereign Bankruptcy Procedures, 113(487) THE ECONOMIC JouRnal 276-304 (2003).

${ }^{57}$ RV Tennekon (n 38) 45.

${ }^{58}$ R. Andritzky, Government Bonds and Their Investors: What Are the Facts and Do They Matter?, IMF Working Paper WP/12/158 (2012).

${ }^{59}$ RV Tennekon (n 38) 145. See also Abaclat (n 15), para 304.
} 
currency of the place of issue and target international investors from different countries. ${ }^{60}$

It is still debatable whether sovereign bonds are loan contracts. ${ }^{61}$ As it will be examined in the next section, the tribunal in Postova Banka's case held that they are not. ${ }^{62}$ This is arguable. But unlike the official and syndicated bank loans, sovereign bonds do not create a direct relationship between the borrower and the multitude of bondholders who purchase their securities on the secondary markets. In as much as the bondholder has legitimate expectations and rights as against the sovereign issuer, it is difficult to argue that there is no privity between the parties as held by some arbitral tribunals. ${ }^{63}$ Like other investors, bondholders are entitled to a return on their investments in the form of interest. Apart from the contextual variations and the peculiar circumstances of the cases to be considered later, it may be argued that excluding bondholders from the meaning of "investors" seems oblivious of the core objectives of sovereign bonds.

From the above, sovereign bonds are species of international bonds issued in capital markets, traded on the secondary markets and target investors worldwide. Thus, the bondholders need not have any direct relationship with the sovereign debtor but they have certain rights as against the debtor. It is submitted that the reciprocal contractual obligations created by the definitive bonds makes it tenuous to argue that no privity of contract exists between the bondholders and the sovereign debtor. ${ }^{6}$

(4) Sovereign Debt as a Treaty Obligation

Like other forms of sovereign debt, it is still debatable whether sovereign bonds constitute a subject matter of investment treaty arbitration. ${ }^{65}$ This raises fundamental questions in the area of debt restructuring. Ordinarily, their enforcement is governed by the contractual documents. Recently however, bondholders have been resorting to ISDS to challenge sovereign debt defaults and restructuring which may have affected their rights with a view to reclaiming the full value of their investment. ${ }^{66}$

\footnotetext{
${ }^{60} \mathrm{Ibid}$, at 148 .

${ }^{61}$ Postova Banka Decision (n 15), para 337.

${ }^{62}$ RV Tennekoon (n 38), 147.

${ }^{63}$ For instance Postova Banka (n 15), para 338.

${ }^{64}$ As held in the Poštová Banka Decision (n 15), para 338.

${ }^{65}$ Nolan and others, Leviathan on Life Support (n 2) 487-512; Brahm, Legitimacy in Global Governance of Sovereign Default (n 7); Waibel (n 2); Norton (n 2); Sandrock (n 2); Thrasher \& Gallagher (n 2).

${ }^{66}$ Abaclat's Decision (n 15): Alemanni v. Argentina (n 15); Ambiente Ufficio S.P.A. \& Others v. Argentine Republic, ICSID Case No. ARB/08/9, Decision on Jurisdiction and Admissibility (8 Feb 2013), https://icsid.worldbank.org/ICSID/FrontServlet?requestType_CasesRH\&actionVal_showDoc\&docId _DC2992_En\&caseId_C340.
} 
Indeed, ICSID tribunals have made pronouncements on this issue as discussed in the next section. The prevailing view is that sovereign debt does not merely give a contractual cause of action; it is also capable of giving rise to treaty claims depending on the context and language of the BIT. ${ }^{67}$ The question is: Can sovereign debt defaults and restructuring qualify as violation of BIT obligations? This too depends to alarge extent on the language of the BIT and the nature of the sovereign debt restructuring in question.

\section{Sovereign Default and Restructuring}

Sovereign default is the inability or refusal of a sovereign debtor to make payments as they become due. ${ }^{68}$ Standard \& Poor describes it as "missed payments on interest or principal of bonds or bank loans". ${ }^{69}$ For sovereign bonds this occurs when the debtor fails a scheduled debt service on the due date or merely exchanges new debts under less favorable terms than the original bonds. ${ }^{70}$ It is principally determined by time and contractual terms. Default usually follows economic crises in the debtor country. ${ }^{71}$ Other triggers include worsening terms of trade, poor macroeconomic policies, increase in borrowing cost, structure of sovereign's debt port-folio, market perceptions, poor sovereign ratings and systemic banking crises. ${ }^{72}$ Any of these factors could lead to either a partial or a complete default. ${ }^{73}$

Regardless of how it emerged, sovereign default naturally affects creditors' rights. But as noted above, legal action upon default raises concerns of enforcement and other challenges. ${ }^{74}$ This is because unlike in corporate insolvency, few (or no) reorganization options exist for sovereign debt in the event of actual or anticipated default. ${ }^{75}$ Sovereign debtors often

\footnotetext{
${ }^{67}$ Abaclat (n 15).

${ }^{68}$ P. Wood, LaW and Practice of InTERnational FinanCe 164 (Sweet \& Maxwell 1980).

${ }^{69}$ Ratings Direct, Default, Transition, and ReCovery: 2014 AnNual SOVEREIGN Default Study And RATing TRAnsitions 26 (Standard \&Poor's Rating Services 2015), https://www.standardandpoors.com/ru_RU/delegate/getPDF;jsessionid=hbpzg4PmQXq1EGd4vSr9Q 9YzGOIybq-7AGTGjVxk1VMcAjDU1h7C!2083099107? articleId=1664058\&type=COMMENTS\& subType=REGULATORY. See also M. Tomz \& M. L. J. Wright, Empirical Research on Sovereign Debt and Default, (2013) NBER Working Paper 18855 9, http://web.stanford.edu/ tomz/working/TomzWright2012-w18598.pdf.

${ }^{70}$ M. Aguair, Sovereign Debt: Empirical Facts (n 43) 8.

${ }^{71} \mathrm{Ibid}$, at $14-17$.

${ }^{72}$ US Das and others (n 47) 6.

${ }^{73}$ Ibid.

${ }^{74}$ Republic of Argentina v. Weltover Inc (1992) 504 U.S. 607.

${ }^{75}$ Waibel (n 2) 712.
} 
restructure their debts in the light of their financial and economic situations. Thus, SDR consists of various methods of altering the repayment plan under the original agreement to respond to actual or anticipated default. It involves "an exchange of outstanding sovereign debt instruments, such as loans or bonds, for new debt instruments or cash". ${ }^{76}$ Its effects include slashing down the expected returns of the creditors. Thus, it could amount to a violation of either the bonds indenture or a treaty obligation. ${ }^{77}$ But default simplicita does not necessarily invoke a state's international responsibility because it is considered as a contractual breach. ${ }^{78}$

Defaults have remained recurring hallmarks of sovereign lending since the medieval times. ${ }^{79}$ An ILA Study Group has found that almost all sovereign debtors have defaulted over the past century and that sovereign defaults tend to occur at the rate of one to three in every year. ${ }^{80}$ Indeed, history has shown that sovereign default affects country's development drive. ${ }^{81}$ In 2002, Argentina made a record-breaking default leading to several litigations before domestic courts mostly in the US. ${ }^{82}$ The creditors expanded their options by filing claims before ICSID tribunals seeking to reclaim their investments. ${ }^{83}$ As will be shown infra, the tribunals handed down ground breaking jurisdiction awards that could have profound impact on the future of sovereign debt restructuring.

While the cases against Argentina were pending, the global financial crises struck in 2008. This leds to increased government borrowing to address budget deficits, plunging so many countries into financial crises and forcing them to default on their sovereign debt commitments. ${ }^{84}$ A notable

\footnotetext{
${ }^{76}$ US Das and others (n 47) 4.

${ }^{77}$ US Das and others, Sovereign Debt Restructurings (1950-2010): Concepts, Literature Survey, and Stylized Facts, IMF Working Paper WP/12/203 (hereafter "US Das and others, Sovereign Debt Restructurings Concepts") 8 (2012).

${ }^{78}$ See C. M. S. Gas Transmission Co. v. Argentine Republic, Award, ICSID Case No. ARB/01/08, Award (12 May 2005) (2005) 44 ILM 1205.

${ }^{79}$ M. S. Tammen, The Precarious Nature of Sovereign Lending: Implications for the Brady Plan, 10 CATO JOURNAL 239 (1990).

${ }^{80}$ ILA (n 50) 4.

${ }^{81}$ K. Rogoff \& J. Zettelmeyer, Bankruptcy Procedures for Sovereigns: A History of Ideas (19762001), 49(3) IMF STAFF PAPERS 470 - 507 (2002) (hereafter "Rogoff \& Zettelmeyer, A History of Ideas") $472-474$.

${ }^{82}$ See for instance, Republic of Argentina v. NML Capital Ltd 134 S. Ct. 2250, 189 L. Ed. 2d 234 (2014), http://www.supremecourt.gov/opinions/13pdf/12-842_5hdk.pdf; E. M. Ltd. v. Republic of Argentina 473 F.3d 463, 481 n.19 (2d Cir. 2007); Aurelius Capital Partners LP v. Republic of Argentina, 584 F.3d 120 (2d Cir. 2009).

${ }^{83}$ P. Di Rosa, The Recent Wave of Arbitrations against Argentina under Bilateral Investment Treaties: Background and Principal Legal Issues, 36 UNIVERSITY OF MIAMI INTER-AMERICAN LAW REVIEW 41-74 (2004).

${ }^{84}$ Nelson, Sovereign Debt in Advanced Economies (n 45) 1-2.
} 
case was the Greek debt default of 2015, which followed series of failed negotiations with the IMF and the Euro Group. ${ }^{85}$ The Greek default also led to another round of claims through investment arbitration. ${ }^{86}$

Therefore, decisions with far reaching effects were made by ICSID tribunals in both the Argentine and Greek debt crises respectively. As reviewed later, these decisions re-echoed the persistent problems of restructuring sovereign debts particularly those incurred by way of sovereign bonds issue.

\section{THE PROBLEMS OF SDR: INTERNATIONAL ARBITRATION TO THE RESCUE?}

Prior to the Argentine debt default, there were some proposals for the use of arbitration in resolving sovereign debt disputes. ${ }^{87}$ But it was the Argentine debt crisis of 2001 that literally opened the "Pandora's Box" ${ }^{\text {" } 88}$ for recourse to ISDS in challenging sovereign debt restructuring. As noted above, sovereign debts create rights under two regimes: treaty and contractual claims. ${ }^{89}$ SDR could affect creditors' rights, which in turn might violatesubstantive and procedural investment guarantees under BITs. For official loans and syndicated bank loans, the IMF, London and Paris Clubs offered different frameworks for relatively orderly restructuring of sovereign debts. ${ }^{90}$ But for sovereign bonds, bondholders seem to be in a dilemma: either accept the sovereign debtor's proposed debt restructuring plan or forego their original claims. There is also the problem of holdout creditors who might frustrate any orderly restructuring. Unfortunately, international finance is still ill equipped to deal with this dilemma. ${ }^{91}$

Therefore, the major problem is the lack of an acceptable, universal legal framework for the enforcement of creditors' claims while balancing the debtors' desire for a return to debt sustainability. ${ }^{92}$ This has been described as "a missing link in international financial architecture" ${ }^{93}$ It is

\footnotetext{
${ }^{85}$ LC Buchheitand M Gulati, How to Restructure Greek Debt, Duke Law School Working Paper (2010), http://papers.ssrn.com/sol3/papers.cfm?abstract_id=1603304 (13 December 2016).

${ }^{86} \mathrm{See}$ for example the Postova Banka Decision (n 15).

${ }^{87}$ J. KAISER, A FAIR AND TRANSPARENT ARbitration Process FOR INDEBTED SOUTHERN COUNTRIES (2001) erlassjahr.de.

${ }^{88}$ Waibel (n 2).

${ }^{89}$ In Alemanni V. Argentina (n 15), para 320, it was held that it is not open to the Claimants to use "this arbitration as a means for vindicating their contractual rights as 'bondholders', but only such rights (and the associated remedies) as they can properly lay claim to as 'investors' under the BIT".

${ }^{90}$ US Das and others, Sovereign Debt Restructurings Concepts (n 77) 14-18.

${ }^{91}$ Ibid, 28.

${ }^{92}$ M. L. J. Wright, Sovereign Debt Restructuring: Problems and Prospects, 2 HARVARD BuSINESS LAW REVIEW 153, 158 (2012), http://www.hblr.org/wp-content/uploads/2012/07/HLB206.pdf.

${ }^{93}$ UNCTAD Sovereign Debt Workout Guide (n 4), 12.
} 
manifested by the disorderly debt restructuring methods with poor creditor coordination, disparate processes and prolonged negotiations. ${ }^{94}$ Although the collective action clauses (CACs) have emerged to remedy the collective action and holdout problems in sovereign bonds, they could not address the "too little, too late" problem. ${ }^{95}$ Other connected problems include lack of institutional legitimacy and inefficiency. ${ }^{96}$

Furthermore, the present SD system has a disparate institutional process of negotiation in the event of default. This is because sovereign debt restructuring largely reflects the nature of the debt itself and the institutional framework, hence bilateral debts, multilateral debts, bank loans and bonds are necessarily treated differently for this purpose. ${ }^{97}$ Except in few cases, multilateral debts managed by IFIs are largely not restructured owing to their special status. ${ }^{98}$ In the case of sovereign bonds, the collective action problem and the possibility of holdouts makes SDR even more complex and challenging. ${ }^{99}$ Despite the provisions for forum selection in bonds instruments, the forum for resolution of disputes arising from sovereign debt default has remained a key challenge for both creditors and debtors. ${ }^{100}$ For the debtor, the multiplicity of creditors and potential suits in multiple jurisdictions poses significant challenges of coordination. ${ }^{101}$ For the "indirect claimants" there is the problem of exclusion due to the informal and non-public character of the negotiations. ${ }^{102}$

In the light of these problems, investment arbitration is gradually being pursued especially to address creditors' dilemma in the event of sovereign debt default and restructuring but not without resistance from sovereign debtors. Interestingly, bondholders find solace in the Washington Convention as they invoke the ISDS provisions and the various investment guarantees under BITs to activate the arbitration machinery. This emerging trend is not uncontroversial as there are contending perspectives with respect to the policy implications of this approach especially in view of some ICSID tribunals' decisions on the subject.

\footnotetext{
${ }^{94}$ Rogoff \& Zettelmeyer, A History of Ideas (n 81) 475-489.

${ }^{95}$ UNCTAD, Sovereign Debt Workout Guide (n 4); T. Jonasson, Lessons from the Recent Debt Crisis, a paper presented at the $10^{\text {th }}$ UNCTAD Debt Management Conference, Geneva, $23^{\text {rd }}-25^{\text {th }}$ (November, 2015) 8.

${ }^{96}$ US Das and others, Sovereign Debt Restructurings Concepts (n 77) 28-30; Brahm, Legitimacy in Global Governance of Sovereign Default (n 7).

${ }^{97}$ UNCTAD Sovereign Debt Workout Guide (n 4), 32.

${ }^{98}$ Ibid, at 32-34.

${ }^{99}$ US Das and others, Sovereign Debt Restructurings Concepts (n 77), 21-28.

${ }^{100}$ RV Tennekon (n 38) 147.

${ }^{101}$ UNCTAD Sovereign Debt Workout Guide (n.4), 34.

${ }^{102}$ Ibid.
} 


\section{The Contending Perspectives And the Position of ARbitral TRIBUNALS}

As noted above, creditors of sovereign debtors, especially bondholders have now resorted to ISDS in challenging sovereign debt restructuring with a view to reclaiming the full value of their investments. However, this is far from generating the needed consensus among scholars and arbitral tribunals. There are two contending views on the use of investment arbitration in claims arising from SDR. The task now is to examine these contending views.

\section{A. Arguments against International Arbitration}

Many scholars have expressed deep skepticisms about dragging sovereign debtors before arbitral tribunals. ${ }^{103}$ Michael Waibel led the skeptics in his seminal article on the subject arguing that at the point of conception of ICSID, sovereign debt was not contemplated as a "typical investment" and that bond contracts in particular contemplate contractual rather than treaty remedies. ${ }^{104}$ The main arguments of the skeptics are summarized below.

\section{Sovereign Debt Claims Are Ill-Suited for Investment Arbitration}

The skeptics contend that ICSID Arbitration was originally tailored for "typical investments" and not sovereign debt. A typical investment must meet some basic tests including the Salini tests: ${ }^{105}$ sufficient duration, territorial link, risk sharing, substantial commitment, regularity of returns and contribution to the development of the host state. ${ }^{106}$ Although some debt instruments were interpreted as falling within the scope of "investment" for ICSID arbitration, ${ }^{107}$ the skeptics argued that ICSID tribunals have no jurisdiction over debt instruments especially sovereign bonds because these are essentially commercial transactions governed by municipal laws and are

\footnotetext{
${ }^{103}$ For convenience we called this group "the skeptics".

${ }^{104}$ Waibel (n 2). See also Kevin P Gallagher, The New Vulture Culture: Sovereign Debt Restructuring and Trade and Investment Treaties, INTERNATIONAL DEVELOPMENT ECONOMICS ASSOCIATES WORKING PAPER No 02/2011, http://www.networkideas.org/working/jul2011/02_2011.pdf (last visited 10 April 2016).

${ }^{105}$ Laid down in Salini Costruttori SpA v. Kingdom of Morocco, ICSID Case No ARB/00/4, Jurisdiction (23 July 2001) 42 ILM 609 (2003).

${ }^{106}$ Waibel (n 2).

${ }^{107}$ Fedax NV v. The Republic of Venezuela, ICSID Case No ARB/96/3, Decision of the Tribunal on Objections to Jurisdiction (11 July 1997).
} 
therefore outside the "core investment" under article 25 of the Washington Convention. ${ }^{108}$

As will be examined infra, this view had influenced both the dissenting opinion in Abaclat and the decision in Postova Banka. The problem with this argument is that it interpreted "typical investment" almost consciously to exclude sovereign debt instruments. For instance, the "sharing of risk" argument that the mere risk of default is inadequate ${ }^{109}$ failed to appreciate the true implication of the word "risk" in sovereign debt-like investments as examined earlier. Secondly, if sovereign debts are "commercial" 110 transactions but not loans, then it seems curious whether it is possible to have a "non-commercial" loan. If both are "commercial" in nature, then it becomes a distinction without a difference.

\section{Exclusive Domestic Jurisdiction in Bonds Contract}

The skeptics also argued that unlike a typical investment, sovereign debts especially sovereign bonds contemplate contractual remedies obtainable in the domestic courts. ${ }^{111}$ They maintained that unlike typical investment contracts, in sovereign bondsthe law of the host state "does not govern the bond; its courts do not enjoy jurisdiction; and bondholders are guaranteed access to an impartial forum" (in other jurisdictions) and therefore using investment arbitration "would undermine legal certainty in the sovereign debt market and... upset long-standing expectations". ${ }^{112}$ They however acknowledged that not all bond contracts confer exclusive jurisdiction on specific domestic courts. The Postova Banka Jurisdiction award equally knocked this argument on its head because the host State's law like in the cases of the so-called typical investment governed the bonds there.

3. Substantive Protections, Holdout Creditors and Policy Considerations

According to the skeptics, most of the substantive investment protections in BITs cannot conveniently address the predicament of

\footnotetext{
${ }^{108}$ Waibel (n 2) 720.

${ }^{109} \mathrm{Ibid}$, at 726.

110 "Commercial" in the sense of arm's length financial dealings and not in the context of ordinary commercial transactions such as contract of sale.

${ }^{111}$ Waibel (n 2) 735.

${ }^{112} \mathrm{Ibid}$, at $733-734$.
} 
creditors of sovereign debtors. ${ }^{113}$ In addition, given the volatility of the sovereign debt markets, the "prompt, effective and adequate" standard of compensation would become nugatory since the market value ex post would be less than the face value of the bonds. ${ }^{114}$ Therefore, the skeptics advocate the inclusion of collective action clause (CAC) and argued that SDR pursuant to a CAC in the bond contract is a mere "modification" amounting to a "contractual restructuring" and not a "sovereign act", which could violate a treaty obligation. ${ }^{115}$ The skeptics also advanced some policy arguments. First, the promise of a successful ICSID arbitration could encourage holdouts and unravel any debt restructuring. Second, investment arbitration could conflict with the institutional roles of the IMF and development banks in addressing debt unsustainability of countries. ${ }^{116}$ Third, international tribunals are incompetent to determine sovereign debtor's payment capacity in the event of an award. Fourth, apart from the likelihood of creditor moral hazard, the number of claims will increase thereby diverting ICSID from its core mandates. ${ }^{117}$

It is clear that the above arguments were advanced to segregate international investment law's established ISDS mechanism from international financial law's undeveloped dispute resolution mechanism with regard to SDR. It is however curious that the peculiarities of one form of sovereign debt (i.e. sovereign bonds) were used to discountenance the use of investment arbitration in SDR regardless of the forms of the debt. In addition, the skeptics were oblivious of the fact that without arbitration of these types of claims by international tribunals, the status quo is one-sided as it does not take cognizance of any "equality of arms" between the contracting parties. In other words, SDR without recourse to arbitration is largely debtor-determined.

\section{B. Arguments in Favor of International Investment Arbitration}

Admittedly, the above arguments raised some legitimate concerns. Apart from the above criticisms however, the arguments were countered by other scholars. ${ }^{118}$ Their arguments which we find more appealing are summarized below.

\footnotetext{
113 Ibid, at $338-754$.

114 Ibid, at 757 .

${ }^{115}$ Ibid, at $736-737$.

${ }^{116}$ Ibid, at 759 .

${ }^{117}$ See J. I. Blackman \& R. Mukhi, The Evolution of Modern Sovereign Debt Litigation: Vultures, Alter Egos, and other Legal Fauna, 73 LAW AND CONTEMPORARY PROBLEMS 49-50 (2010).

${ }^{118}$ Norton (n 2); Sandrock (n2).
} 
1. The Coverage of Sovereign Debts Depends on the Intention of Parties to BIT

It is tenuous to argue that sovereign debt instruments are ill suited for investment treaty arbitration on account of the so-called typical investments because investment arbitration, like other aspects of international law, is founded on the parties' consent. ${ }^{119}$ If the parties to a BIT expressly included sovereign debt instruments as "investments", then an arbitral tribunal must respect the parties' intention. ${ }^{120}$ Indeed, parties' intention seems to implicitly favour investment arbitration since both before and after Argentina'shistoric default, countries signed BITs without express exclusion of sovereign debt instruments from the covered investments in the treaty. This is a clear indication of countries' intention to include sovereign debts as covered investments. There should therefore be a general presumption in favor of sovereign debt instruments except where expressly excluded. ${ }^{121}$ This is because serious negotiations always precede the conclusion of BITs.

In addition, contractual and treaty claims are not mutually exclusive. ${ }^{122}$ The "umbrella clause" in BITs enables investors to have recourse to investment treaty arbitration. Indeed, once a claim meets the conditions for jurisdiction and admissibility, it can be adjudicated upon regardless of the availability of a cause of action in contract ${ }^{123}$ as "a State may breach a treaty without breaching a contract, and vice versa." "The important condition is that once submitted to ICSID, the other forum lacks jurisdiction over the same claims. ${ }^{125}$

\section{Substantive Protections, Holdout Creditors and Policy Considerations}

SDR normally follows a specific sovereign act usually in the form of

\footnotetext{
${ }^{119}$ MD Nolan and others, Leviathan on Life Support (n 2) 578 - 510.

${ }^{120}$ Malaysian Historical Salvors $v$. The Government of Malaysia, ICSID Case No ARB/05/10, Decision on the Application for Annulment (16 April 2009), paras 73-79.

${ }^{121}$ They are debt instruments having direct nexus with the host state. See for instance, Deutsche Bank $A G$ v. Democratic Socialist Republic of Sri Lanka ICSID Case No ARB/09/02 Award (31 October 2012), paras 288 and 292.

${ }^{122}$ See for instance Lanco International Inc v. Argentine Republic Case No ARB/97/6, Preliminary Decision on Jurisdiction 8 December 1998 (2001) 40 ILM 457; SGS SociétéGénérale de Surveillance SA v. Islamic Republic of Pakistan, Decision on Jurisdiction 6 August 2003.

${ }^{123}$ E. Gaillard, Investment Treaty Arbitration and Jurisdiction over Contract Claims-the SGS Cases Considered, in T .Wieler (ed.) INTERNATIONAL INVESTMENT LAW AND ARBITRATION: LEADING CASES FROM THE ICSID, NAFTA, BILATERAL TREATIES AND CUSTOMARY INTERNATIONAL LAW, 325.

${ }^{124}$ Compañía de Aguas del Aconquija SA and Vivendi Universal v. Argentine Republic, Decision on Annulment, 3 July 2002, 19(1) ICSID Review-FILJ, paras 95-96 (2004).

${ }^{125}$ CDC Group Plcv Republic of the Seychelles ICSID Case No ARB/02/14.
} 
legislative measures that often affect creditors' rights as happened in Argentina and Greece. Regardless of the economic justifications, these measures, depending on the context and the terms of the BIT, could touch on a debtor's treaty obligations such as those of non-expropriation, FET, NT and MFN. ${ }^{126}$ Secondly, far from undermining the institutional roles of IMF in sovereign debt crises management, an enforceable arbitral award could make this institutional intervention unnecessary ${ }^{127}$ thereby avoiding the diplomatic complications which could "undermine a key purpose of international investment agreements-the promotion of foreign investment." $" 128$

On the incompetence of ICSID tribunals to determine a sovereign debtor's capacity to repay, the proponents argued that the alternative is even worse since it allows the debtor and domestic courtsthe powers to do the same. ${ }^{129}$ Indeed, an arbitral institution might develop consistent and uniform principles for this purpose.

\section{Equality of Bargaining Power and other Policy Arguments}

As noted earlier, an effective, depoliticized adjudicating forum to resolve claims arising from SDR provides a level-playing ground for both creditors and their sovereign borrowers. The proponents maintain that presently exchange offers are done largely on the debtor's terms, on a takeit-or-leave-it basis and this lacks transparency as it completely ignores creditors' voice. ${ }^{130}$ This makes SDR a one-sided affair. ${ }^{131}$ It goes against the contractual spirit that the skeptics emphasized on. In addition, judgments of national courts may face enforcement constraints including sovereign immunity. Therefore, investment arbitration could provide the needed balance with a promise of compliance. This is because under the Washington Convention, arbitral awards are final, binding and enforceable in all member countries. ${ }^{132}$ This could in turn create creditor confidence in the debt market leading to a "greater access to financing for all states". ${ }^{133}$

\footnotetext{
${ }^{126}$ Abaclat (n 15).

${ }^{127}$ Norton (n 2) 303.

${ }^{128}$ Ibid.

${ }^{129} \mathrm{Ibid}$, at 304.

${ }^{130} \mathrm{Ibid}$, at 301 .

${ }^{131}$ After the Argentine exchange offer of 2005 Gelpern noted that "Argentina's crisis seems to suggest that default shifts the balance of power in favour of the debtor absent official intervention". See A Gelpern, "After Argentina" Institute of Intl Economics, Policy Briefs in International Economics, No PB 05-2, 9 (2005).

${ }^{132}$ Washington Convention (1965) Articles 53 and 54.

${ }^{133}$ Norton (n 2) 302.
} 
Therefore, flowing from the above, it is submitted that the emerging trend in sovereign debt claims seems to clearly favor the second view. This position will be clearer with the aid of arbitral jurisprudence, which we now turn to.

\section{The Perspective of ICSID Tribunals}

It is important to evaluate the growing trend from the perspectives of ICSID arbitrators in at least three jurisdiction awards. The conclusions support the claim that investment arbitration is a viable answer to some of the problems of SDR.

\section{Abaclat v. Republic of Argentina}

Following the debt crisis of the 1980s, Argentina restructured its economy. ${ }^{134}$ It issued 179 bonds worth over US $\$ 186.7$ billion in both domestic and foreign capital markets. ${ }^{135}$ Out of the 179 bonds, 173 were denominated in foreign currencies and the Claimants allegedly purchased 83 of the 173 foreign currency bonds, which were governed by the laws of different jurisdictions and traded on various capital markets around the world. ${ }^{136}$ By the late 1990s, the Argentine economy was in deep recession and by December 2001 it defaulted over US $\$ 100$ billion of external bond debt. ${ }^{137}$ Following the enactment of the Public Emergency and Reform Law of 2002, Argentina lunched two Exchange Offers in 2005 and 2010 respectively. The Emergency Law prohibited a re-opening of the Offers thereby preventing eligible but un-exchanged bonds from being renegotiated. The claimants did not participate in both Exchange Offers. They filed their request for arbitration before ICSID challenging, among others, the unilateral debt restructuring as expropriation and a violation of the FET standard under the Italy-Argentina BIT, 1990. ${ }^{138}$ Argentina questioned ICSID tribunal's jurisdiction arguing that it was "an unprecedented abuse of the investment treaty regime" and "a legally unsupported attempt to turn a sovereign's non-payment of external debt into a violation of investment treaty protection". ${ }^{139}$ Since the bondholders purchased their security claims on the secondary markets, it argued that they were not investors as

\footnotetext{
${ }^{134}$ P. Di Rosa, The Recent Wave of Arbitrations against Argentina (n 83) 41-74.

${ }^{135}$ Abaclat (n 15), 681-683.

${ }^{136}$ Ibid.

${ }^{137}$ Ibid, at 683.

${ }^{138} \mathrm{Ibid}$, at 714 .

${ }^{139} \mathrm{Ibid}$, para 234.
} 
contemplated by the Washington Convention. Interestingly, Argentina advanced a policy argument against the claim insisting that ICSID tribunal proceedings were inappropriate in claims arising from SDR and would be "counterproductive" 140 as holdout creditors were "the biggest threat to the stability and fairness of sovereign debt restructuring." 141 The claimants responded that "opening the door to ICSID arbitration would create a supplementary leverage against such rogue debtors and therefore be beneficial to the efficiency of foreign debt restructuring."

The majority decision of the tribunal disagreed with the position of Argentina and held that the tribunal has jurisdiction over "investments" by way of sovereign bonds, noting that issues of public policy were for the parties to consider at the point of negotiating the BIT. ${ }^{143}$ However, in his dissenting view Prof. George Abi Saab held that the Washington Convention did not "foresee" or contemplate sovereign bonds as covered investments and assuming jurisdiction by the tribunal will lead "to tenuous anduntenable interpretations ... over-stretching the text beyond the breaking point, in order to extend jurisdiction to where it does not exist..." ${ }^{\text {144 }}$. Prof. Abi Saab did not however answer another vital question that he raised at the end of his opinion: "what is the proper and prudential course for ICSID tribunals to take in this regard?" 145 We shall revisit this question after reviewing the other cases.

\section{Alemanni v. Republic of Argentina ${ }^{146}$}

The background facts in this case were similar to those of Abaclat's. Based on the formal default by Argentina, the claimants alleged breaches of the guarantees under the same BIT with respect to FET and the prohibition of expropriation. Among other objections to the jurisdiction of the tribunal, Argentina argued that "investment arbitration is an inherently unsuitable and unacceptable way of dealing with default on sovereign bonded debt". ${ }^{147}$

The tribunal held that the complaints "are capable of constituting a breach of one or more of the provisions of the BIT". ${ }^{148}$ It held that as investors under a BIT, the claimants could use arbitration to enforce their

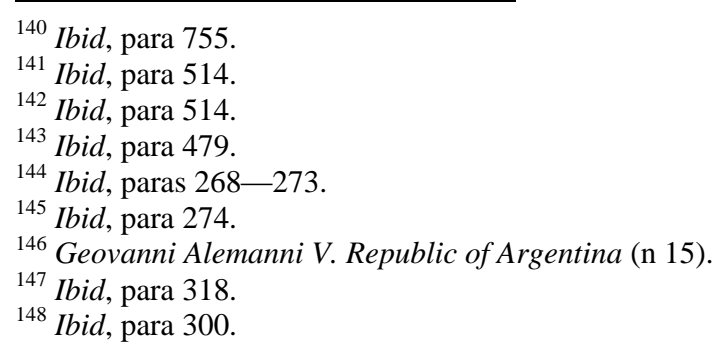


claims. While disagreeing with the dissenting opinion of Prof. Abi Saab in Abaclat, which imported "policy considerations into one area while vigorously rejecting them in others", the tribunal held "As a fact of international economic life, sovereign bond issues were plainly within the normal field of contemplation of the Contracting Parties." "149

\section{Postova Banka and Istrokapital SE v. Hellenic Republic}

The global financial crises of 2008 led to the downgrading of Greek sovereign bonds including the ones held by the claimants. ${ }^{150}$ Unlike the situation in Abaclat, the Greek law governed the bonds in contention. ${ }^{151}$ The Greek government issued the bonds to the participants of the Bank of Greece's Securities System. The participants delivered the bonds to the primary dealers who provided the funds and sold the bonds on the secondary markets. ${ }^{152}$ The financial situation of the country deteriorated despite the intervention of the IMF and the Euro Group. In 2012, the Greek Bondholder Act was enacted paving way for the debt restructuring. ${ }^{153} \mathrm{~A}$ Private Creditor-Investor Committee negotiated a haircut on the face value of the Greek debt and the government declared this to be the only available offer to bondholders. ${ }^{154}$ Through their intermediary, the claimants rejected the Exchange Offer and filed a request for arbitration to reclaim the value of the bonds. Greece raised objection to the jurisdiction of the tribunal and the tribunal upheld the objections. ${ }^{155}$

After examining the peculiarities of sovereign debt, the tribunal distinguished the facts of the case from Abaclat's and held that the BITs under which the claims were filed excluded the sovereign bonds in question as "investments". ${ }^{156}$ Curiously however the tribunal held that since the bonds were purchased at the secondary market through an intermediary, there was no privity of contract between the parties. ${ }^{157}$ But even if there was privity, the crucial point is that the parties to the BIT hadexcluded sovereign bonds from ICSID's arbitration. The tribunal held that "Loans and bonds are distinct financial products." 158

\footnotetext{
${ }^{149} \mathrm{Ibid}$, para 320.

${ }^{150}$ Postova Banka Decision (n 15), paras 44-65.

${ }^{151}$ Pursuant to Law 2198 of 1994.

152 Postova Banka Decision (n 15), para 54.

${ }^{153} \mathrm{Ibid}$, para 67.

${ }^{154}$ Ibid, para 72.

${ }^{155} \mathrm{Ibid}$, paras $229-289$.

${ }^{156} \mathrm{Ibid}$, paras $284-305$.

${ }^{157} \mathrm{Ibid}$, paras 344-349.

${ }^{158}$ Ibid, paras 335-338.
} 
From the above arbitral jurisprudence, it is obvious that investment arbitration could be used in addressing claims arising from sovereign debt default. The determining factor is the language of the BIT under which the claims were founded as well as the intention of the parties. A definition of "investment" broad enough to include sovereign bonds will evince a clear intention to invoke the ISDS provisions in BITs and likely to receive the nod of ICSID and other arbitral tribunals in claims arising from SDR. Parties' BITs should determine whether it is included or excluded. ${ }^{159}$

\section{INVESTMENT ARBITRATION AND THE GAP IN THE LEGAL FRAMEWORK ON SDR}

What emerged from the above decisions is that it is plausible and prudent (reverting back to Prof AbiSaab's unanswered question) for international tribunals to assume jurisdiction over claims arising from sovereign debt defaults where the parties to BITs either expressly or by necessary implication included sovereign debts as covered investments. This, it is respectfully submitted, is more in line with the spirit of the progressive development of international law, itself anchored on the consent of states. ${ }^{160}$ Policy considerations and historical conjectures must not be employed to undermine this fundamental principle. In the light of the problems of SDR framework, it is submitted that investment arbitration could aid in filling the existing vacuum on sovereign debt governance because parties' consent is also the fulcrum of ISDS. In other words, the use of arbitration could address the age-long vacuum in international finance with respect to SDR because of the significance of parties' consent. ${ }^{161}$ Parties to BITs should determine the continued relevance of arbitration in SDR. No special regime of international law can ignore the position of parties' consent. ${ }^{162}$ Negating parties' consent is simply doing violence to the root of international law itself. Indeed, international finance and international investment have the same purpose: to promote smooth commercial intercourse and support economic development of nations through the involvement of private and

\footnotetext{
${ }^{159}$ A. Viterbo, Tension between International Investment Protection and Financial Stability, 17TH INVESTMENT FORUM, BIICL, $\left(9^{\text {th }}\right.$ September 2011$)$ slides $11-13$ (2011), http://www.biicl.org/files/5794_viterbo_09-09-11_biicl.pdf (last visited 2012/16). ${ }^{160}$ M. N. Shaw, InTERnational Law 9-11 (6 $6^{\text {th }}$ edn, Cambridge University Press 2012$)$. ${ }^{161}$ On the place of consent see AM Steingruber, Notion, Nature and Extent of Consent in International Arbitration (Ph.D. Thesis, School of International Arbitration, Queen Mary University of London 2009).

${ }^{162}$ ILC, Fragmentation of International Law: Difficulties arising from the Diversification and Expansion of International Law, REPORT OF THE STUDY GROUP OF THE INTERNATIONAL LAW Commission (C. Koskenniemi) UN Doc A/CN.4/L682, 193 (13 April 2006).
} 
institutional capital providers.

Second, it is historically incorrect to detach sovereign debt from the underlying objectives of ICSID. ICSID was established to, among other objectives, provide "an international tribunal in the field of financial and economic disputes with Governments". ${ }^{163}$ Claims arising from or connected with sovereign debt default are arguably within the scope of "financial and economic disputes with Governments". This is the umbilical connection between sovereign debt and international investment law as it relates to dispute settlement mechanism. Thus, international arbitration is clearly a major point of intersection between international financial law and international investment law. ${ }^{164}$

Third, while the calls for a multilateral framework on sovereign debt restructuring continue to make analogies with corporate and sub-national insolvency regimes, ${ }^{165}$ they tend to ignore the fact that a fairly balanced and effective SDR could also operate in the "shadow" of international investment law. This may address the one-sidedness of the present debt restructuring system. In fact, arbitral awards on sovereign debt defaults could actually empower the parties while at the same time minimising the politics that accompany institutional interventions in the matter.

Fourth, history has shown that the involvement of arbitral tribunals in sovereign debt crisis resolution is not really a new phenomenon. ${ }^{166}$ Indeed, at a point they "were the only form of adjudication that proved remotely effective at resolving disputes arising out of sovereign default". ${ }^{167}$ Investment treaty arbitration should therefore be seen as a continuation of the age-long efforts towards finding a normative framework that could create a level-playing ground between the parties and specifically address creditors' dilemma in SDR. In addition, ICSID tribunals could conveniently adjudicate over "loans" other than sovereign bonds contracts. In this situation, the existence of a BIT with substantive and procedural investment guarantees could form the basis for a claim by the creditors.

\footnotetext{
163 Y. Krayvoi (n 36).

164 J. Ostřanský (n 2).

165 See A. O. Krueger, A New Approach to Sovereign Debt Restructuring (International Monetary Fund 2002); IMF, Proposals for a Sovereign Debt Restructuring Mechanism (2003), available at http://www.imf.org/external/np/exr/facts/sdrm.htm; K. Raffer, Applying Chapter 9 to International Debt: An Economically Efficient Solution with a Human Face, 18(2) WORLD DEVELOPMENT 301311 (1990).

${ }^{166}$ WMCWeidemaier, Origin of Sovereign Debt Arbitration (n 10) 340.

${ }^{167}$ Ibid.
} 


\section{A. $\quad$ The Future of Investment Arbitration in SDR}

Even as investment treaty arbitration is creating the level-playing field for parties and is "depoliticising" sovereign debt crises across the world, experience has shown that it has its downsides in the typical ISDS. ${ }^{168}$ It exposes the debtors to the jurisdiction of arbitral tribunals and States are becoming suspicious. ${ }^{169}$ Indeed, there is an on-going effort to increase recourse to the alternatives of ISDS through arbitration with emphasis on prevention policies. ${ }^{170}$ Because of its peculiar nature, investment arbitration raises concerns of high cost, case management, legitimacy and fairness, coherence and legal certainty. ${ }^{171}$ As noted above, ICSID has its own challenges. ${ }^{172}$ These and other problems contribute to the search for alternatives. Thus, there is a gradual move towards conciliation, mediation and negotiation as well as dispute prevention policies through engagement in inter-institutional information sharing within states. ${ }^{173}$ These are however far from providing the needed guarantee.

\section{CONCLUSION}

The advantages offered by investment arbitration have over the years contributed in stabilizing the international investment regime. Sovereign debt must not be detached from this system except where the parties to any IIA expressly agreed to do so. From their inception, IIAs have played pivotal role in building and cementing economic relations among nations with a common goal of enhancing economic cooperation and development as well as opening opportunities for nationals of the respective parties. Interestingly, ISDS and substantive investment protection provisions feature in these IIAs to create a level-playing field for disputing parties. IIAs are often the products of long negotiations hence inclusion or exclusion of sovereign debt instruments as a subject matter of arbitration should be a matter for the parties to decide in the light of the fundamental place of consent in international law. States can control their participation in ICSID arbitration through conscious exclusion of SD or other unwanted claims at the point of negotiating a BIT. Opting out of the Washington Convention is

\footnotetext{
${ }^{168}$ Robert M. Ziff, The Sovereign Debtor's Prison: Analysis of the Argentine Crisis Arbitrations and the Implications for Investment Treaty Law, 10 Rich J GLOBAL L \& Bus 345, 380-381 (2011).

${ }^{169}$ I. A. Vincentelli, (n 14).

${ }^{170}$ UNCTAD, Investor-State Disputes: Prevention and Alternatives to Arbitration (n 24).

${ }^{171}$ Advisory Council on Intl Affairs, (n 17) 25-26.

${ }^{172}$ L. E. Trackman, The ICSID Under Siege, 4 CORNELL InTERNATIONAL LAW JouRnAl 5604 (2012).

${ }^{173}$ UNCTAD, Investor-State Disputes: Prevention and Alternatives to Arbitration (n 24).
} 
certainly another option, but it is a costly option especially for the developing countries. States must either rethink/remodel their BITs to exclude sovereign debts instruments from the jurisdiction of ICSID tribunals or they must be presumed to have implicitly consented to investment treaty arbitration.

In fact, the fear of creditor action itself could instill financial discipline to ensure proper utilization and management of foreign loans. While empowering bondholders and other creditors to use arbitration, it could also minimize institutional intervention by IMF and reduce moral hazard problems. Countries in need of foreign investments must balance their interests with those of their investors and creditors. The reservations against investment arbitration must be carefully addressed rather than rejecting it completely. A recent study found that "ISDS claims are directly proportional to FDI stock" and that "the growth in ISDS claims and the growth in outward FDI stock follow a similar trend". ${ }^{174}$ In fact, more developed states are increasingly being subjected to the ISDS mechanisms. ${ }^{175}$

Admittedly, sovereign debt restructuring consistently present challenges because of economic uncertainties, political risks and a clear absence of a comprehensive legal framework to govern such restructuring. It also opens the gate for vulture funds actions. ${ }^{176}$ These however must not preclude creditors from submitting claims for arbitration in a depoliticized and more effective forum, which both the sovereign debtor and the home state of the creditors consensually agreed by way of treaty. Policy considerations must give way to prior consent of the parties. The direct and indirect advantages of ICSID and other arbitrations to the sovereign debt scheme are too enormous to ignore on the basis of technical gymnastics. Apart from effective and efficient enforcement, there is the "equality of arms" between the parties. In addition, one cannot ignore the fact that sometimes principles emerge out of adjudication. Although ICSID arbitration is not precedent-based ${ }^{177}$, the tribunals could aid in developing consistent, predictable and uniform principles that might form the basis for a normative framework on SDR globally. Investment arbitration could

\footnotetext{
${ }^{174}$ See Investor-State Dispute Settlement: A Reality Check, A Report by the Scholl Chair in International Business at CSIS7.

${ }^{175}$ See UNCTAD, Recent Trends in IIAs and ISDS, IIA Issues Note, No 1 (UNCTAD February 2015) 5 .

${ }^{176}$ C. Olivet \& Eberhardt, Profiting from Crises: How Corporations and Lawyers are Scavenging Europe's Crisis Countries, TRANSNATIONAL InSTITUTE AND CORPORATE EuROPE OBSERVATORY 6, 36 (2014).

${ }^{177}$ Washington Convention Article 53(1) (1965). See also, AI Umar, Precedent...BUJPL.
} 
therefore be a basis for the progressive development of this aspect of international law.

Finally, as promising as investment arbitration isin SDR it is not shielded from many challenges especially regarding costs of proceedings, length of proceedings, efficiency and unpredictability of outcomes. Preproceeding disputes prevention measures should be introduced into sovereign debt dispute management. ISDS cannot prevent sovereign debt disputes totally, but it canminimize them. This is an important window which should therefore remain open except where State parties to BITs expressly close such window. 